\title{
Cirsoid aneurysm of the scalp: case report
}

\author{
Flávio Ramalho Romero', Gabriela Roncada Haddad², \\ Eberval Gadelha Figueiredo ${ }^{3}$, Manoel Jacobsen Teixeira ${ }^{4}$ \\ Serviço de Neurocirurgia do Hospital Ipiranga - SUS, São Paulo, Brazil.
}

\begin{abstract}
We report a case of a 23-year-old man presented with a painful swelling over his right occipital region. Selective right carotid angiogram demonstrated a markedly tortuous and dilated right occipital artery feeding into a circular or cirsoid aneurysm in the right occipital scalp. Percutaneous occlusion of the cirsoid aneurysm was not attempted and the patient underwent a successful resection of the fistula with good outcome after three months followed up.
\end{abstract}

\section{KEYWORDS}

Cirsoid aneurism, scalp arteriovenous fistulas.

\section{RESUMO}

Aneurisma cirsoide do couro cabeludo: relato de caso

Relatamos um caso de paciente masculino de 23 anos com lesão pulsatile em região occipital direita. Angiografia digital seletiva da artéria occipital direita mostrou artéria occipital direita dilatada e tortuosa formando aneurisma cirsoide do couro cabeludo. Oclusão percutânea não era possível e o paciente foi submetido à ressecção cirúrgica da fístula com sucesso. O seguimento em três meses mostrou boa recuperação.

\section{PALAVRAS-CHAVE}

Aneurisma cirsoide, fístula arteriovenosa do couro cabeludo.

\section{Introduction}

Cirsoid aneurysms are rare arteriovenous fistulas of the scalp. They are usually congenital in etiology. However, traumatic fistulas have also been described. ${ }^{2-4}$ The term "cirsoid aneurysm" is used because this lesion resembles a varix; the derivation of cirsoid is from the Greek word kirsos, or varix. ${ }^{1-3}$ The superficial temporal artery is the most commonly involved artery. ${ }^{1,4}$

Patients usually present with a pulsatile disfiguring scalp mass which can be extensive and grotesque. Other presenting symptoms include headache, pulsatile tinnitus, and hemorrhage from the lesion following minor head trauma. ${ }^{1,3}$ Treatment options include surgical resection, endovascular occlusion, and direct percutaneous injection of sclerosing agents. ${ }^{5}$ The radiological findings are important for patient management. ${ }^{1,5}$

\section{Case}

A 23-year-old man presented with a painful swelling over his right occipital region. On examination, a pulsatile occipital scalp mass was detected, with large visible draining veins. There was a small area of skin ulceration over the mass but no active bleeding. On auscultation, a bruit was detected over the lesion. The neurological examination was normal. The patient underwent selective four-vessel angiography. Selective right carotid angiogram demonstrated a markedly tortuous and dilated right occipital artery feeding into a circular or cirsoid aneurysm in the right occipital scalp (Figure 1). Large draining veins were noted running anteriorly toward the vertex and posteriorly toward the occiput. There was evidence of drainage into the sagittal and transverse sinuses and superior cortical veins via

1. Neurosurgeon of Hospital Ipiranga, São Paulo, Brazil, postgraduated student of Neurosurgery Division of São Paulo University (USP), Brazil.

2. Demartologist of Clinica Stockli, São Paulo, Brazil.

3. Head of Neurovascular Group of Neurosurgery Division of Hospital das Clínicas of Medical School of USP, Brazil.

4. Head Neurosurgery Division of Hospital das Clínicas of Medical School of USP, Brazil. 
the calvarial emissary veins (Figure 1). Because of the intracranial venous drainage, percutaneous occlusion of the cirsoid aneurysm was not attempted and the patient underwent a successful resection of the fistula. He made a complete recovery with no recurrence of the fistula at the three-month follow-up examination. Patient consented with this report.
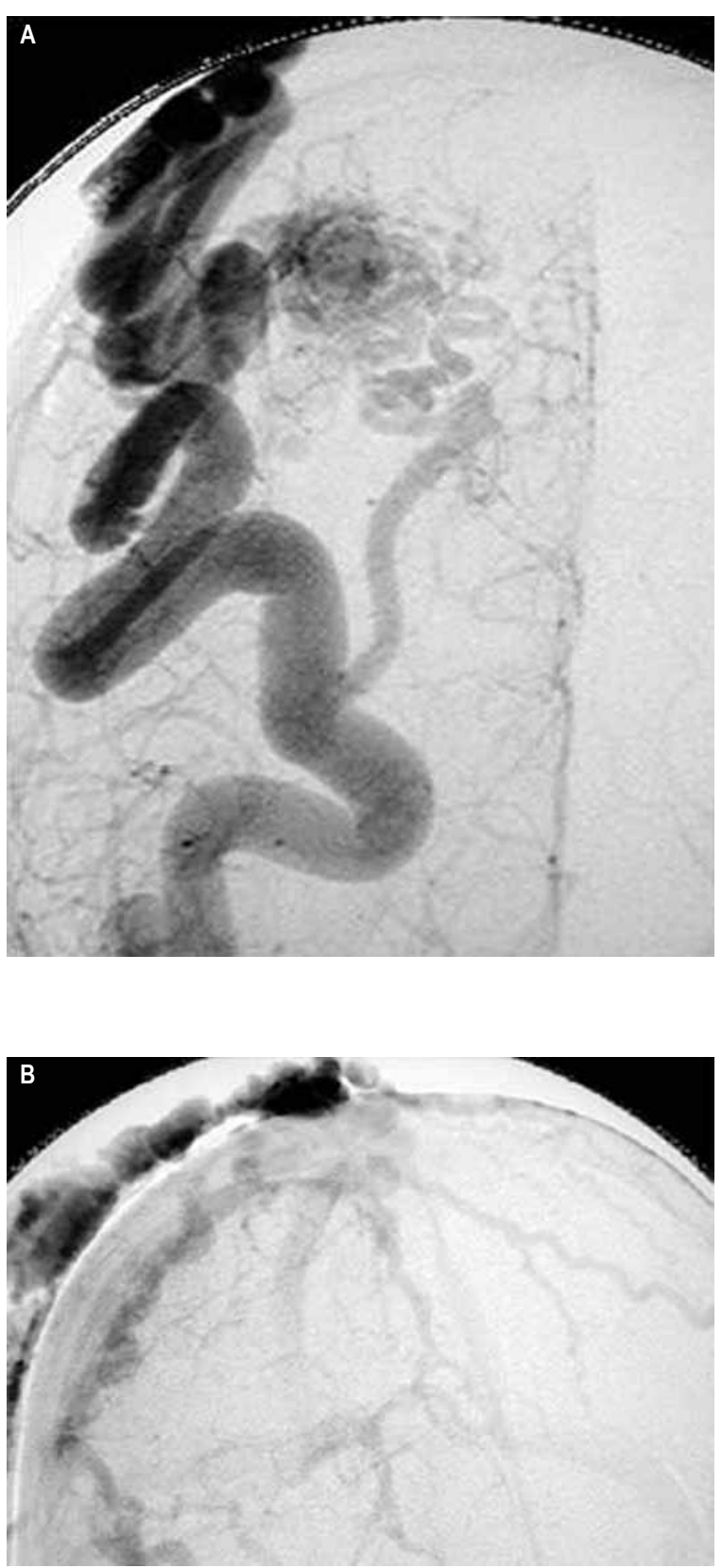

Figure 1 - Selective right carotid angiogram shows a markedly dilated right occipital artery feeding into the fistula in the right occiput (Figure 1A) and venous phase angiogram shows the venous pouch and dilated serpiginous-draining superficial and cortical veins from the fistula. Deep venous drainage into the venous sinuses and superior cortical veins of the brain is present (Figure 1B).

\section{Discussion}

Cirsoid aneurysms of the scalp occur infrequently and can be difficult to remove. Since the early 1800's, numerous reports of cirsoid aneurysms have appeared in the literature. ${ }^{1,3,4}$ Initial attempts at ligation of feeding arteries proved ineffective. Ligation of feeding vessels followed by resection of the lesion has occasionally met with success. Other reported treatments include radiation therapy, electrothrombosis, scalp tourniquet, ${ }^{2,4}$ scalp compression with pads and springs ${ }^{4}$ direct injection with alcohol, and embolization. ${ }^{1,2,5}$

Untreated patients can develop progressive scalp and facial cosmetic deformity from the markedly tortuous subcutaneous vessels. However, this condition is not life-threatening. ${ }^{1,2}$ Surgical resection of the fistula is usually successful, as was for this patient. ${ }^{1}$ Multiple treatment schemes have been described and, as yet, no standard form of therapy exists. Direct surgical excision risks severe intraoperative blood loss. ${ }^{1,2}$

Endovascular and percutaneous occlusion of the fistulas have been described. The results of endovascular occlusion are dependent on the angioarchitecture of the fistula, the supplying arteries and draining venous structures. Arterial approaches may not often be successful in occluding the entire fistula due to the problem of multiple feeding arteries being recruited to supply the fistula. Occlusion of the venous pouch usually requires later surgical removal of the embolic material. ${ }^{3-5}$

\section{References}

1. Barnwell S, Halbach VV, Dowd CF, Higashida R, Hieshima G. Endovascular treatment of scalp arteriovenous fistulas associated with a large varix. Radiology. 1989;173:533-9.

2. Chatterji P, Purohit GN, Soni NK. Cirsoid aneurysm of the auricle and adjoining scalp. J Laryngol Otol. 1977;91:9971001.

3. Fisher-Jeffes ND, Domingo Z, Madden M, de Villiers JC. Arteriovenous malformations of the scalp. Neurosurgery. 1995;36:656-60.

4. Gurkanlar D, Gonul M, Solmaz I, Gonul E. Cirsoid aneurysms of the scalp. Neurosurg Rev. 2006;29:208-12.

5. Hurwitz DJ, Kerber CW. Hemodynamic considerations in the treatment of arteriovenous malformations of the face and scalp. Plast Reconstr Surg. 1981;67:421-32.

\section{Endereço para correspondência}

Flávio Ramalho Romero

Rua Pascoal Vita, 366, ap. 94, Vila Madalena

05445-000 - São Paulo, Brazil

Phone: (11) 3459-4416/(11) 9714-7720

E-mails: frromero@ig.com.br/romeroncr@gmail.com 